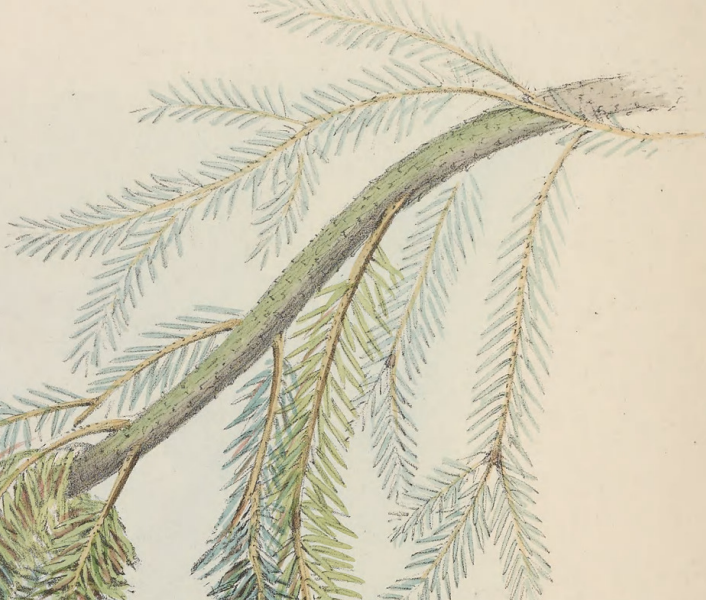

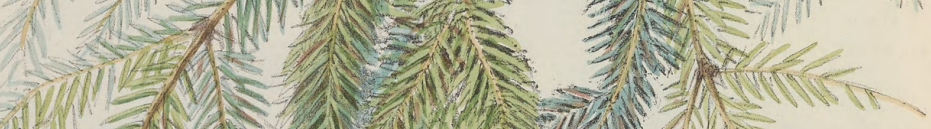

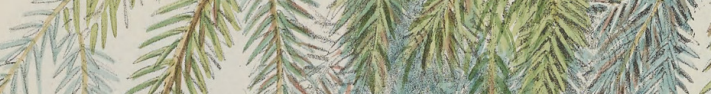
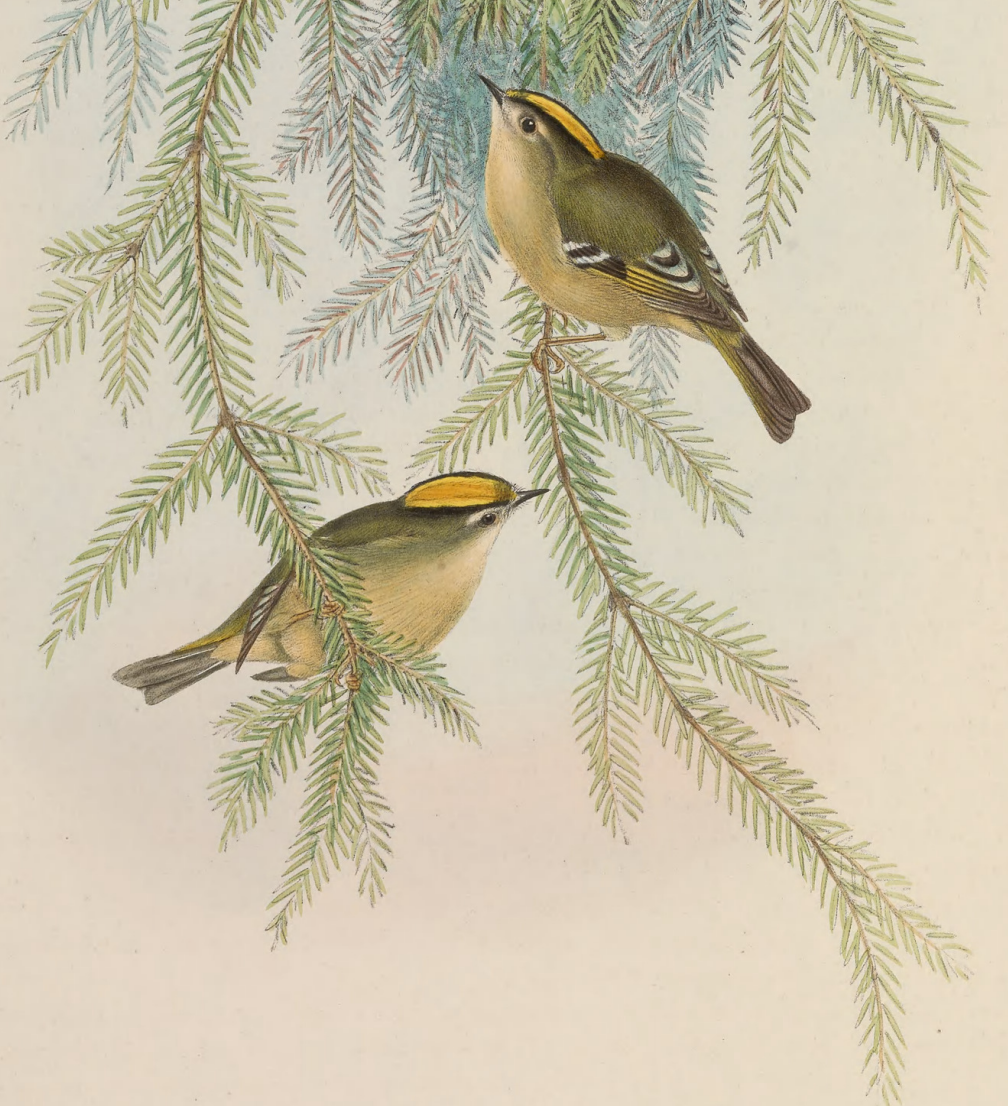


\title{
REGULUS HIMALAYENSIS, Blyth.
}

\author{
Himalayan Goldcrest.
}

Regulus cristatus, Blyth, Cat. of Birds in Mus. Asiat. Soc. Calcutta, p. 186. -v. Pelz. Ibis, 1868, p. 308.

"Regulus Himalayensis, Blyth," Jerd. Birds of India, vol. ii. part i. p. 206.

Тнат the avifauna of India should be destitute of a member of the grenus Regulus could not have been even suspected, since the form occurs in Asia Minor on the west, and in Amoorland and Japan on the east. It is strictly a northern genus, no species being found to the southward of the equator. In the New World two species occur, one, R. satrapa, in North America, and the other, $R$. (Regruloides) calendula, in Mexico. In the Old World we find $R$. ignicapillus, $R$. cristatus, and $R$. Maderensis, the two former of which are spread over Europe and North Africa, while the third appears to be confined to the island of Madeira. The five birds above mentioned are regarded as true and distinct species by every ornithologist, while that represented on the opposite Plate (R. Himalayensis) and the R. Japonicus of Bonaparte are considered to be of questionable specific value. Now, as I have before me specimens of $R$. cristatus collected in England and France, of $R$. Japonicus from the island whence it derives its name, and a fine male specimen from the Himalayas, I will point out the differences, slight or otherwise, which I find to exist among these distantly located examples. As is the case with many other nearly allied species of Europe and Japan, the Reguli inhabiting those countries very closely assimilate, while they differ from the bird found in the Himalayas, the latter being considerably larger in size, having longer wings, and the centre of the crest of a paler hue, or not so intensely orange as in either of its congeners; in every other part of their plumage all three are very similar. After this brief notice of the little difference which really exists between $R$. cristatus, $R$. Japonicus, and $R$. Himalayensis, ornithologists must form their own opinion as to whether they are really three distinct, or only one and the same species. Those who take the latter view will hold that the $R$. cristatus ranges over the greater part of the Old World, from Ireland to Japan; and this may be the true state of the case : whether it be or be not, it becomes my duty to give a place to the Himalayan Goldcrest in 'The Birds of Asia.' I close these remarks with stating my belief that if a number of European, Himalayan, and Japanese specimens were mingled together, a competent ornithologist would have no difficulty in deciding to which country each belonged. The admeasurements of birds cannot be depended upon; but I repeat that I find the Himalayan bird to be larger than that of Japan, which, again, somewhat exceeds the size of the favourite little Goldcrest of Europe.

Of the $R$. Himalayensis very little is known; Mr. Jerdon merely mentions that it is "very like the Regulus cristatus, but larger, and the flame-coloured interior of the crest more developed.

"The Himalayan Fire-crested Wren has only been found in the N. W. Himalayas, and, even there, apparently not very common.'

Von Pelzeln in his paper on "Birds from Thibet and the Himalayas," after mentioning that Dr. Stoliczka met with the bird at Kotegurh in winter, remarks, " most careful comparison has convinced me of the specific identity of the European and Asiatic birds."

General colour olive-green, becoming somewhat yellow on the rump, and more grey on the under surface; lores grey; superciliary stripe brown, above which is a streak of black; centre of the crown yellowish orange, bordered externally with paler yellow; lesser and greater wing-coverts yellowish white, forming two bands across the wing; primaries dark brown, margined externally with olive, and with a black spot at the base of the sixth, seventh, and eighth; bill black; feet brownish flesh-colour.

Total length $3 \frac{5}{8}$ inches, bill $\frac{7}{16}$, wing $2 \frac{1}{4}$, tail $1 \frac{1}{1} \frac{1}{6}$, tarsi $\frac{3}{4}$.

The figures are somewhat less than the natural size. 


\section{$2 \mathrm{BHL}$ Biodiversity Heritage Library}

Gould, John. 1869. "Himalayan Goldcrest, Regulus himalayensis, Blyth. [PI. 60]." The Birds of Asia 4(XXI), -. https://doi.org/10.5962/p.322996.

View This Item Online: https://www.biodiversitylibrary.org/item/120503

DOI: https://doi.org/10.5962/p.322996

Permalink: https://www.biodiversitylibrary.org/partpdf/322996

\section{Holding Institution}

Smithsonian Libraries

\section{Sponsored by}

Smithsonian Institution Libraries

\section{Copyright \& Reuse}

Copyright Status: Not in copyright

This document was created from content at the Biodiversity Heritage Library, the world's largest open access digital library for biodiversity literature and archives. Visit BHL at https://www.biodiversitylibrary.org. 